\title{
Towards the eradication of tobacco addiction in Canada: The role of the physician
}

\begin{abstract}
$\mathrm{T}$

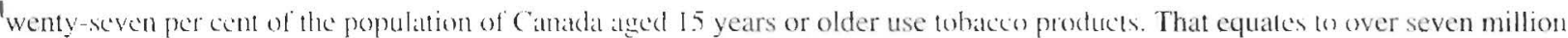
people of whom onc in live will dic ol a cigarette-related disease. Seventy-live per cont of these individuals want to quit. and five oult of wix wish they had never stitricat.
\end{abstract}

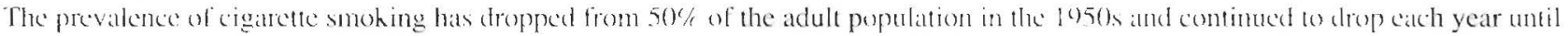

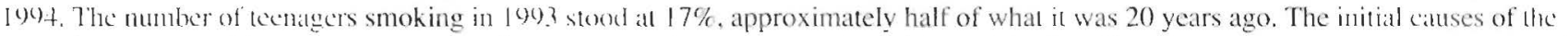
reduction were multilatorial, party due to increated public awareness of the risks and the benefits of cessation, partly due to the reduction in advertising, partly duc to the warnings placed on cisarctle packages and mont certainly duc to the very siscable increases in the price of cigarettes.

Since February 1994, with the lobacco tax rollback in Canada, more teenagers and preteens have begun to sinoke. Previous dittil thom Health (andat have indicated that it is this segment of the population which is most sensitive to the price ol tobacco. 1994 was the year of the greatest increase in tobaces consumption in recorded Canadian history. The tobacco tax reduction in log + may well rank as the worst public health fiasco perpetrated by any Canadian government. It is also potentially a very expensive blunder as one in four of the nkw smokers will develop a cigarette-related disease, and one in five will die because of it.

Why do ternatgers begin to smoke! Initially the cause is peer pressure and cigarette advertising; subsequently nicoline addiction develops tollowed by psychologicical conditioning.

Why do people comlinuc to smohe even if they want to quit? Primarily, in most individuals, it is because of nicotine attiction and at combintion of emvirommental and emotional eues as a result of psychological conditioning and reinforcement hy each cigarette smoked.

Recent research into why a person starts smoking and those factors that maintain the habit have enabled physicians, psychologists and phatmatcologists to approath at smoking cessation success rate that has not been possible previously.

A number of nodilities have been shown to be effective in smoking cessation. The first and simplest of these is physician advice. Firm advice from a doctor wilh counselling. provision of litcrature and follow-up has been shown to result in cessation in a significant number ol smokers. This is particularly true il the person has a moking-related disease. And yet only about $60 \%$ of doctors even ask all their paticnts if they smoke.

If the smoker is determined by the physiciatl to have at significant component of nicotine addiction, nicotine replacement therapy is indicated. This can be accomplished with the nicolinc palteh or nicotine gum depending on individual circumstances. If these agents are prescribed, the paticnt slould be fully acyuaned with the correct usage and potential side effects. For example, if the person continues smoking while using the nicotine patches. the nicotinc in the blook maly rise to levels that are potentially hazardous to patients with unstable heart disease.

Behaviour modification is an essential component of the smoking cessation process. All smokers trying to quit should be referred to the L.ung Association or equivalent program for instruction in those aspects of behaviour modification most applicable to him or her. These techniqucs address the environmental ind emotional cucs so important in sustaining the habit in most smokers.

The combinalion of physictan advice, nicotine replacement and behaviour modification, with follow-up by the physician or a formal smoking cessation program, has becu shown lo result in documented quit rates of 25 to $30 \%$ verified biochenically.

The other factors shown to be relevant in cessation are social. If the spouse and friends don't smoke and the environment at work is nomsmoking, there is a greater likelibood of the smoker quitting. Untortunately, however, the riverse is true if the spousc. frituds and work assuciales do smoke, the likelihoud of success is significantly diminished.

As important as the acomplishment of cessation by current smokers is the prevention of intiation of the tobacco !abit in lecragers. A total of $40.0(1)$ Candians die each year of cigarette-related diseases, approximately 110 deaths daily. Thus, the tobaccu industry needs 10 induce addiction in 110 Canadian teenagers each dity just to retain the market. It behooves every physician to exert any influence he or slu mat have upun their clected officials to reinstituk tobacco laxes in those provinces where they have been reduced, ban all cigarette advettising, initiate the use of plain (generic) packaging and remove cigarette machines from areas accessible to teenagers. The organizalion 'Physicians for a Smoke Free Canada' works actively towards these objectives, and they should be supported in their efforts.

Wilh the improved understanding of the development of addiction and maintenance of the habit and the new therapeutic modalities. we ate closel than we have ever been to climinating eventually the curse of tobacco smoking, the major cause of preventible kath in our socicly lodily. 


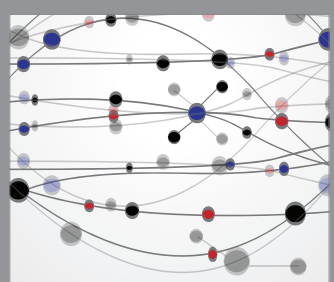

The Scientific World Journal
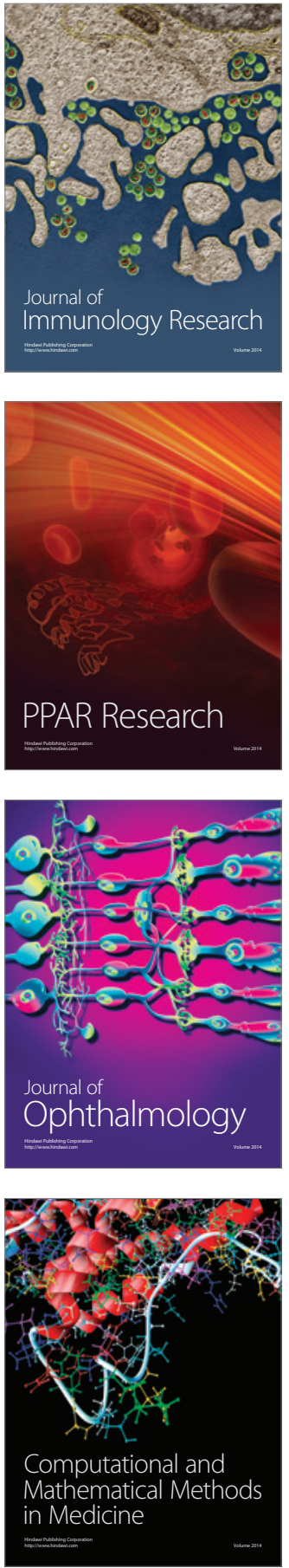

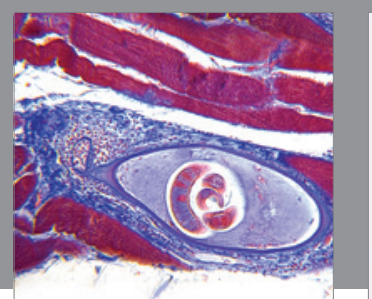

Gastroenterology Research and Practice

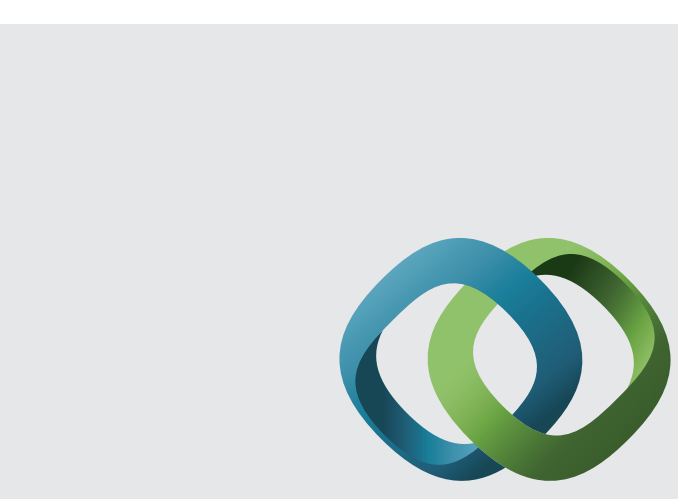

\section{Hindawi}

Submit your manuscripts at

http://www.hindawi.com
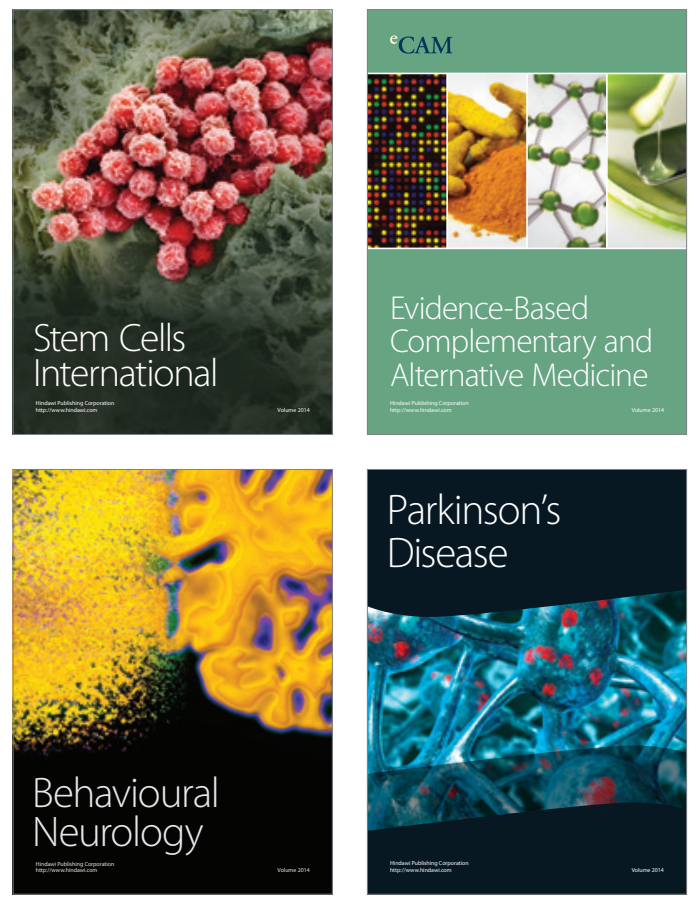
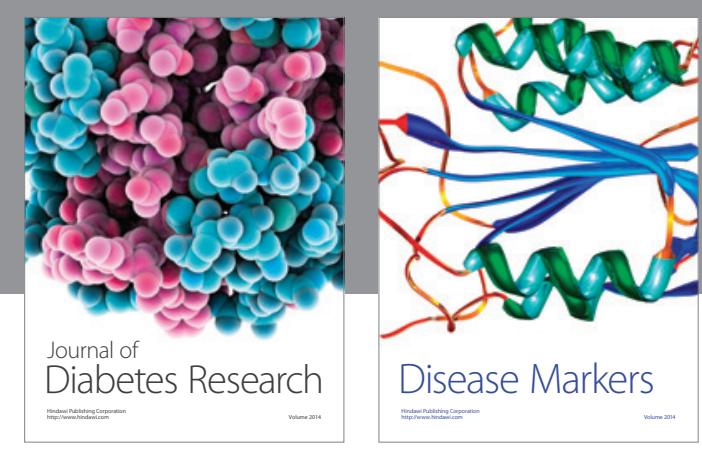

Disease Markers
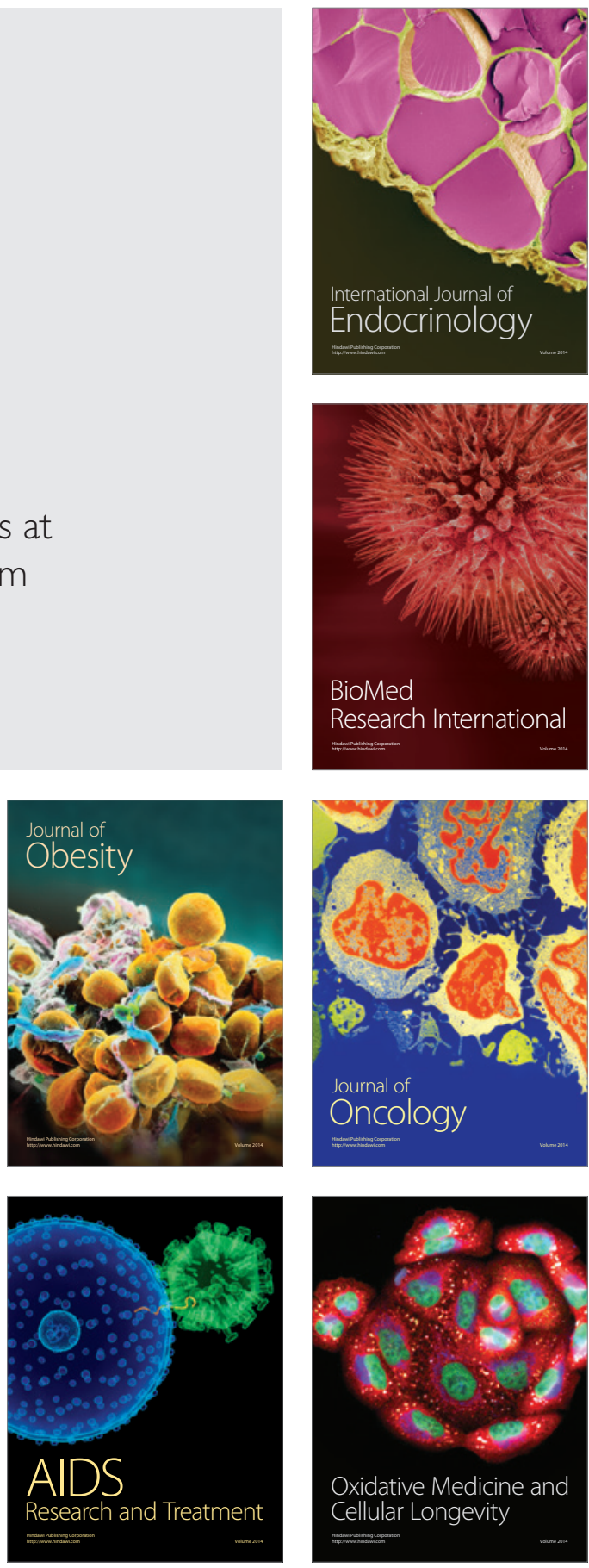